\title{
Grief and Emotional Suffering in Dutch Funeral Elegiac Poems by Jeremias de Decker and Michiel de Swaen,
} c. $1650-1700$

\section{Cornelis VAN DER HAVEN}

Cornelis van der Haven is associate professor at Ghent University in the field of early modern Dutch literature. He studied Comparative Literature at Utrecht University and wrote a dissertation about the institutional dynamics of early modern theatre repertoires in the context of urban culture. He has published widely about the history of Dutch and German theatre and literature in the seventeenth and eighteenth centuries, with a strong focus on the role of literary texts in shaping cultural and social identities. He is currently working on a book with the provisional title Enlightenment at War. Epic Poetry, the Citizen and Discursive Bridges to the Military (1740-180o).

\begin{abstract}
Both Protestantism and Catholicism of the seventeenth century experienced the influence of theology that stressed the importance of inner devotion, which went hand in hand with a strong emphasis on the emotional experience of faith. In dealing with death, however, the discourse of comfort was still dominant, designed to suppress the pain of loss rather than bringing that feeling to the fore. This 'emotional regime' also affected funeral elegiac poems in which feelings of joy and delight about the deceased's heavenly destination dominate the initial period of grief. This article aims to understand whether these emotional regimes induced a form of emotional suffering and, if so, to what extent this was visible in contemporary funerary poetry: did, for example, it stick to grief and the inner pain of loss instead of suppressing it? The essay focuses on the elegiac poems by Jeremias de Decker (1609-1660) in the Dutch Republic and by Michiel de Swaen (1654-1707) in French Flanders. It examines the striking differences between the elegies written after the passing away of a public person, such as befriended priests and preachers, and the poems about a death in the private sphere in which poetry functioned more as a means of emotional refuge.
\end{abstract}

Keywords: elegy, poetry, emotional suffering, Pietism, Counter-Reformation, death

DOI 10.51750/emlc10010 - URL: http://www.emlc-journal.org

Publisher: Stichting EMLC

Copyright: The Author(s). This work is licensed under a Creative Commons Attribution-NonCommercial 4.0 International License. 


\section{Grief and Emotional Suffering in Dutch Funeral Elegiac Poems by Jeremias de Decker and Michiel de Swaen,} c. $1650-1700$

\section{Cornelis van der Haven}

From emblematic poems to epitaphs and songs: death and moral questions relating to the finiteness of human life are omnipresent in early modern poetry. This article focuses on one specific lyrical genre, that of elegy and the epicedium in particular, the official Latin name for funerary lamentation as a subgenre of elegy. ${ }^{1}$ The Dutch term for epicedium is lijkzang, a word that refers to a poem about the corpse of the deceased, but also read in the presence of that corpse (literally: before the corpse), for instance during the funeral itself. In some cases, this performative function of the epicedium continued to exist in the early modern period, but even where it disappeared, at least the idea of 'speaking before the corpse' remained present in these poems. The lijkzangen under scrutiny here were written in Dutch by two poets: the Amsterdam poet Jeremias de Decker (1609-1660), and Michiel de Swaen (1654-1707), who lived in Dunkirk, in French Flanders, a territory of the Spanish Low Countries that had been annexed by France.

The elegy was a popular genre amongst many Renaissance poets. Central to its power were emotions such as the pain of loss, grief, but also joy in the deceased's merits and virtues. Many of the elegies were occasional poems written following the death of a friend, a relative, or other acquaintances of the poet, others were composed to mourn the death of princes, local rulers, or dignitaries. ${ }^{2}$ In these poems, the emotional experience of grief had to be suppressed in order to create feelings of joy and delight about the deceased's heavenly destination. In the seventeenth century, however, both Protestantism and Catholicism were influenced by theologies that stressed the importance of inner devotion and this went hand-in-hand with a strong emphasis on the emotional experience of faith. In the Northern Netherlands, this was associated with the so-called movement of Pietism, both within Calvinism as well as in other protestant denominations, like Anabaptism. In the Southern Netherlands and French Flanders, too, the emotions of the individual believer played an important role, especially in literature that was written in the context of the Counter-Reformation. 
In this article, I will focus on the emotional functions of the early modern epicedium. Remembering a deceased person through reflections on his or her physical remains is strongly linked to the idea of consolation (consolatio) in the tradition of early modern elegy. The physical aspects of the dead body can play a role in this, as well as the bodily and mental effects of the passions that the description of the corpse caused in the mind of the lyrical I. Certain emotions are evoked by the poems - such as pain, sorrow, and horror - in order that they might be replaced by other feelings, including appreciation or resignation. This way of manipulating emotions can be seen as an effect of the discussed poems that connects them to the rules of a certain 'emotional regime'. ${ }^{3}$ Early modern neo-stoicism could, for instance, be understood as an emotional regime that prescribes how to deal with emotions and which feelings one should or should not cherish in certain situations.

The emotional response to death in the elegies written by de Decker and de Swaen will be discussed in the light of a dominant emotional regime that demanded the suppression of grief and inner pain, while in certain religious emotional communities of the time, there was rather a tendency towards highlighting such emotional responses to death that can be related to the above-mentioned 'Pietism'. This tension between the demands of the overarching emotional regime and the emotional culture within smaller religious communities could also induce 'emotional suffering' based on 'goal conflicts' on an individual level. ${ }^{4}$ To follow the rules of an emotional regime often means that individuals are confronted with certain 'goal conflicts', as in a regime that asks for emotional control in the situation of personal loss, whereas we could actually only handle that loss if we have the opportunity to express our grief. ${ }^{5}$ The strong emphasis on emotions in the work of de Decker and de Swaen has been analysed by scholars mainly from a rhetorical conceptual framework, with an emphasis on the genre conventions of early modern lyrical poetry, but not from the perspective of an emotional regime and the emotional suffering it produces. ${ }^{6}$ Before analysing the poems and their religious context, I will first discuss Reddy's concepts in relation to the rhetorical conventions of the elegiac genre between 1650 and 1700, as well as the emotional handling of death in funeral poetry.

\section{Grief and Emotional Suffering}

With the remains of the deceased as their lyrical object, lijkzangen refer to the physical presence of a person, even though that person is spiritually absent. The object of an epicedium contains a problem which, according to the literary scholar Roland Greene, determines the genre of elegy: 'The problem of addressing something not present in or to the poem.' ${ }^{\prime}$ As we shall see, de Decker even makes the absent person explicitly present by, for example, letting the deceased speak to his wife. Moreover, both de Decker and

3 Reddy, Navigation of Feeling.

4 Reddy, Navigation of Feeling, 126-127.

5 Reddy, Navigation of Feeling, 121.

6 See Konst, 'De retorica van het "movere"'; Smit, Kalliope in de Nederlanden, 621-633.

7 Greene, 'Elegy, Hymn, Epithalamium, Ode', 315. 
de Swaen make the deceased physically present through describing their physical appearance during the transformation from living bodies to corpses. In both cases we can consider the poems as attempts to make the dead present among the living, as we see in reflections on how the corpse may remind the next of kin of the significance of the deceased while they were living, a 'holding fast of the dead among the living', as Gadamer has put it. ${ }^{8}$

By enabling the reader to imagine the presence of the individual who has died, elegies invite the reader to go through an emotional process that is related to the feeling of loss. The lyrical I in these poems often refers quite explicitly to the different mental states of this emotional process. William Reddy has called such references 'emotives', that is: verbal statements as expressions of certain emotions that are both constative and performative in nature. Talking about our emotions, we already 'feel' how they work in relation to the dominant emotional regime, or to express it in Reddy's words: emotive is an utterance that both 'describes (like constative utterances) and changes (like performatives) the world, because emotional expression has an exploratory and self-altering effect on the activated thought material of emotion'. ${ }^{9}$ Early modern poetry is full of such emotional claims. When a lyrical I names certain emotions, he or she alters his or her emotional state and possibly also the reader's. This is the performative side of emotives: talking about emotions does not only mean that we simply describe certain feelings, but it could also be considered as a way to change, strengthen, hide, or intensify them, according to Reddy. ${ }^{10}$

On the one hand, elegies can be considered as an expression of the regime's normative emotions, but on the other hand it may be possible to consider them as an 'emotional refuge' for those who would like to express feelings that are suppressed by the emotional regime. Reddy's example for such a 'refuge' are the salons and lodges of the early eighteenth century that provided 'safe release from prevailing emotional norms' until the second half of that century, when a new emotional regime of sentimentalism became dominant. ${ }^{11}$ The concept, however, could also refer to relationships and rituals that 'provide safe release from prevailing emotional norms and allow[s] relaxation of emotional effort'. ${ }^{12}$

Most of the early modern funeral elegies in the Dutch tradition have a fairly traditional rhetorical structure, hardly offering any 'emotional refuge'. That rhetorical structure is focused on the wish to overcome feelings of loss and replace them with inner tranquillity and thankfulness towards God. ${ }^{13}$ The poems start with praise for the deceased (laus), followed by a lamentation about their death (luctus), which culminates in the search for consolation (consolatio). Although most poets have held to these three main rhetorical elements, Brady has noticed that in the English tradition at least there was also a tendency of 'resistance' towards this rhetorical structuring of elegies, for instance in poems that omit he final part, consolation. ${ }^{14}$ This opposition of poets towards the dominant rhetorical 
and literary conventions of their time will be an important point of interest in what follows, in which I will discuss these conventions in Dutch poetry in the light of the religious context and emotional regime in which the poets and their elegies were situated. Perhaps this 'resistance' can be seen as a response to emotional suffering, as poetry provided an 'emotional refuge' for avoiding the moment of consolation and (re)experiencing the pain of loss and the awareness of death, instead of denying those feelings or putting them in the shade of the consolatio that has to follow upon the luctus. Both in de Decker's and in de Swaen's oeuvre, there is a striking difference between the elegies mourning a public person and the poems about a death in the private sphere. De Decker wrote a cycle of five funeral elegies about the death of his father, while de Swaen wrote one epicedium about the death of a good friend, a notary who was murdered in his office. Before I move to the poems that are connected to the private life of both poets, I will discuss some of their more formal or 'public' funeral elegies.

\section{Comforting Poems}

Only three funeral elegies by Michiel de Swaen have survived, one about his friend and two about the death of local Dunkirk clergymen: Jan van de Knocke (d. 13 April 1700), the chaplain of the Augustinians, and the priest Joseph de Bousy (d. 27 October 1699). The latter poem was published posthumously in 1722, the other two have survived in manuscript. If they ever have been printed during the lifetime of de Swaen is uncertain. The two formal poems about the clergymen have a fairly traditional rhetorical structure as discussed in the previous section. The expressed grief ends with comfort offered by a higher authority: Saint Barbara in the case of de Bousy (the patroness of a local confraternity), and God in the poem about van de Knocke.

In both poems the community of mourners is explicitly addressed and the lyrical I makes them aware of what should be the collective source of comfort: faith. The poems also explicitly ask the mourners to put an end to their grief, referring to the salvation that the deceased will surely find in the afterlife because of his good works. In the poem about van de Knocke, the lyrical I states that the community would be very insensitive, 'if it could face this death without pain'. ${ }^{15}$ It is more important, however, to rejoice in the good work that the chaplain has done in his life and the certainty that God will reward him for those good works: 'Because he has lived so faithfully before God,/It is fair that God now rewards him.' ${ }^{\text {'6 }}$

Both poems also contain much praise for the deceased clergymen. Halfway through the poem about van de Knocke, the entire city of Dunkirk is addressed in order to highlight the chaplain's good works: 'Rise up, Dunkirk, citizens speak, cry out, from every corner/ Where Mr. Knocke came to visit and comfort you. ${ }^{17}$ The townspeople act here as wit-

15 De Swaen, Werken van Michiel de Swaen, vi, 146: 'Indien het dese doot con aensien sonder pyn.'

16 De Swaen, Werken van Michiel de Swaen, vi, 147: 'Want, naer hy voor syn Godt soo trouwigh heeft geleeft,/'t Is billyk, dat hem Godt nu syn vergeldingh geeft.'

17 De Swaen, Werken van Michiel de Swaen, vi, 146: 'Ryst Duynkerk! borgers spreekt, roept uyt, van alle hoecken/Waer u d'heer Knocke quam vertroosten en besoecken.' 
nesses in the laus, relating how he has cared for his parishioners during his lifetime. This poem therefore can also be characterised as a hymn rather than an elegy, and the title Vreugde-sangh (song of joy) is significant in that sense. The praise of van de Knocke even precedes the sadness about his death. The first stanza immediately shows great confidence in the 'infinite retribution' that the chaplain will receive in heaven, because he died 'in the favour and pure love of the Lord'. ${ }^{18}$ Only after these expressions of praise and joy there are references to the grief over his death - a grief that emerges and is immediately smothered by the joy that should prevail here.

The following rhetorical question is posed in the second stanza of the poem: should the community mourn or rejoice over the chaplain's good works? The answer follows quickly in the third and fourth stanza. A short period of deep collective grief is justified, but soon after that, sorrow has to be tempered, followed by delight:

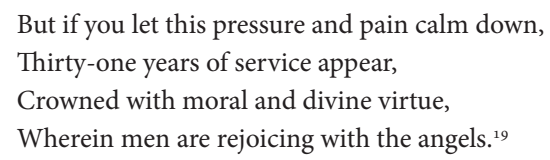

It is striking that the abandonment of the pain and inner pressure occurs almost automatically: one can simply let these feelings calm down to make room for good memories. Someone who has lost a dear one can decide to mourn, but he or she can also decide to let that sorrow settle down and let it merge with joy over the soul's salvation. It is not without reason that the poem begins with a reference to Revelation 14:13: 'Blessed are the dead who die in the Lord.' Praise and comfort are inextricably linked here: the good works of the deceased bring comfort, because they guarantee that he or she is with God, who will reward the dead for their good works.

In de Decker's more formal elegies laus and consolatio also overshadow utterances of grief. De Decker was a member of the Dutch Reformed Church but he also attended services in the Walloon Reformed Church in Amsterdam. His poem on the death of Godefroy Hotton (d. 16 June 1656), minister of that church, begins with expressions of disbelief about the death of this man, followed by praise for his great merits as a minister who has successfully spread God's word. ${ }^{20}$ There is exactly one verse that touches briefly upon the luctus, which is immediately surpassed by the consolation: 'Alas! One cannot escape death!' ${ }^{21}$ After this exclamation, however, the pain of loss is immediately put in perspective: the preacher has indeed been silenced by death, but because this wise man has put his words on paper, one can still hear his voice through his writings. As is typical for the Calvinist context, consolation here is not found in the salvation of the soul due to the good works of the deceased, but in God's grace and the power of Scripture. The preacher's writ-

18 De Swaen, Werken van Michiel de Swaen, VI, 145: 'oneyndige vergeldingh', 'in des Heeren jonst en reyne min'.

19 De Swaen, Werken van Michiel de Swaen, vi, 146: 'Maer, als men desen druk en weedom laet bedaeren,/ Vertoont sigh eenen dienst van een en dertigh jaeren,/Verciert met zedelyke en goddelyke deught,/Waer in de menschen syn met d'Engelen verheugt.'

20 De Decker, Rym-oeffeningen, 80-82.

21 De Decker, Rym-oeffeningen, 81: 'Helaes! de dood is niet t'ontslippen.' 
ten sermons are connected with the Word of God, which brings the man himself closer to the heavenly father.

In his poem, de Decker emphasizes the power of the word by praising the rhetorical ingenuity of the preacher, but also by stressing how important it is that the recipient allows Hotton's words to act on him and to 'move' him or her 'inwardly':

\author{
It will be his eloquence \\ That you will taste in his learned pen. \\ In short, you will see all things written \\ Like they were expressed, [...] \\ In such a way that, inwardly moved, \\ You will exclaim: as long as the sun \\ Gives the day to our eyes, \\ So Hotton will relive in Job, \\ And Job will teach us through Hotton. ${ }^{22}$
}

The aim of being moved inwardly connects this poem to the meditation techniques of Protestant Pietism, as expressed, for example, in the main theological work of Gisbertus Voetius, Praktijk der godzaligheid (chapter twenty-one), one of the leading figures in the so-called Nadere Reformatie (Further Reformation). In this work, the Utrecht theologian explains the art of dying well (ars bene moriendi) to his readership. ${ }^{23}$ Piety in this work not only refers to devotion but also to a highly emotionalized relationship of the believer with God, from deep sadness about the sins committed, to the great joy of the grace of Christ. Voetius's emphasis on spiritual meditation connects this Calvinist version of Pietism in an interesting way with the Catholic tradition. Meditation in this case aims at removing the objections against death and replacing them with motives that can arouse a longing for death.

Despite his strong objections against the Catholic tradition, Voetius refers to several late medieval Christian mystics as he attempts to find a definition for meditation. ${ }^{24}$ One of the definitions he uses comes from the work of the fifteenth-century authority on dying, Jean Gerson, who had stressed the importance of feelings in meditation, referring to them as 'the supreme joy of the mind that transcends the earthly'. ${ }^{25}$ What is typical for orthodox Calvinism, however, is the strong emphasis on scriptural reflections when explaining meditation practices, like in de Decker's references to Hotton's sermons: his written and spoken words would necessarily increase the believer's knowledge of the Scripture, but they should also lead to inner emotional reflection and a deeper understanding of God's word. ${ }^{26}$

Consolation (consolatio) in de Decker's poem about Hotton can be found in the example of Job that is taken from the sermons of the deceased. ${ }^{27}$ Comfort should be taken from the

22 De Decker, Rym-oeffeningen, 82: 'Ghy sult daer sijn' welsprekentheyd/In sijn' geleerde pen hersmaken;/ Kortom ghy sult daer alle saken/Soo sien geschreven als geseyt. [...]/Sulcx dat ghy innerlijck bewogen/Uytroepen sult: soo lang de Son/Sal dag aen onsen oogen geven/Soo sal Hotton in Job herleven,/En Job ons leeren door Hotton.'

23 Voetius, De praktijk der godzaligheid, 444-445.

24 Voetius, De praktijk der godzaligheid, 53-54.

25 Voetius, De praktijk der godzaligheid, 54.

26 De Decker, Rym-oeffeningen, 82.

27 Hotton, La pieté éprouvée. 
fact that Hotton lives on through his writings, as Job does through his lived example of faith. Comfort also plays a role in de Decker's other elegies for people with a certain public profile, such as Daniel Arminius (d. 1649), the son of theologian Jacobus Arminius. ${ }^{28}$ Arminius jr. was a young doctor who suddenly died. The sorrow surrounding his death resounds in the poem by way of explicit lamentations ('Ach! ach!'), but soon that luctus is interrupted by the consolation found here in the belief that the young doctor's soul will continue to exist after his death, 'ascended to eternity', redeemed from its earthly existence. In heaven, 'where is no sighing or weeping', he will be reunited with his dear ones and with God. ${ }^{29}$

In Protestant handbooks from the time, both people who expected to die soon and their kin were comforted with a similar message, just as in the case of Voetius, who points to all the pleasant and sweet things that the believer will enjoy in heaven..$^{30}$ The importance of comfort in pastoral care and meditation practices of the believer can hardly be underestimated for this seventeenth-century branch of Pietism. Voetius even devoted an entire chapter to 'consolation', in which he describes consolatio both as a 'signified act' that 'provides relief or resistance to sorrow and fear, through the perception of a greater good' and as a 'performed act' that depends on the strength and content of the chosen words of the comforter and how the comfort seeker allows them to act on his mind through the religious practice of meditation..$^{31}$

\section{Satisfied Grief by Lamentation}

Michiel de Swaen is one of the poets traditionally associated with the Counter-Reformation, mainly due to his epic poem about the life and death of Christ (Het leven en de dood van Jesus Christus, published posthumously in 1767), which can be considered as the Catholic equivalent of de Decker's work on the passion of Christ (Goede Vrydag ofte Het Lijden onses Heeren Jesu Christi, 1651). ${ }^{32}$ Yet, as has been indicated by Porteman and Smits-Veldt, there are important similarities between de Decker and de Swaen, as they both placed strong emphasis on the emotional and sensual experience of the implied reader in their work. ${ }^{33}$ The suffering of Christ is described in all its details, from the hammering hammers on the cross, through to the tears flowing down the faces of his followers and everything is described in a way designed to appeal the reader's senses, inviting him or her to contemplate on Jesus's suffering.

The Pietistic tendencies in the work of de Swaen could be explained by similar tendencies in different branches of Catholicism around 1700, especially in the theological

28 De Decker, Rym-oeffeningen, 79-80.

29 De Decker, Rym-oeffeningen, 80: 'opgevoert na d'eeuwigheyd', 'daer noyt gesucht word noch geschreyt'.

30 Voetius, De praktijk der godzaligheid, 446.

31 Voetius, De praktijk der godzaligheid, 571: 'het opbeuren en versterken van onze ziel als tegenwicht tegen een actueel, dreigend of te vrezen kwaad, door de overdenking en toepassing op de eigen omstandigheden van een groter goed'.

32 See for instance Buitendijk, Het calvinisme in de spiegel, 336-348.

33 Porteman and Smits-Veldt, Een nieuw vaderland voor de muzen, 816-817. 
movement of Jansenism, which in its conception of salvation leaned towards Protestantism yet maintained a spiritualized practice of the seven sacraments at its core. ${ }^{34}$ Over the course of the seventeenth century, there was also an increasing emphasis on spirituality, inner devotion, and an emotional experience of faith within the Jesuit order. In the context of the Counter-Reformation in the Southern Netherlands, several Catholic songbooks appeared that stressed the importance of emotions in worship, such as the songbook by Daniël Bellemans that focused on an internalized relationship of the believer with God. ${ }^{35}$ Drawing on these songbooks, scholars like Hoppenbrouwers have argued for a tendency towards Pietism during the Counter-Reformation, both in the Southern Netherlands and in the Dutch Republic. ${ }^{36}$

The religious use of art - in this case poetry - to integrate a 'bodily, sensual, and emotional immersion' when inviting the believer to an emphatic response to the displayed suffering of Christ, was a key element of the late medieval Catholic tradition of meditation. ${ }^{37}$ The resemblances between the Counter-Reformation and Protestant Pietism in regard to their emphasis on emotions may have something to do with the fact that both movements drew inspiration from late medieval devotion, in particular the 'rhetorically inspired pathopoeia, its conscious crafting of the believers' emotions through their daily devotional practices'. ${ }^{8}$ We know from the important work by Karant-Nunn on religious emotions that the 'emotional scripts' of Lutheranism, Calvinism, and Catholicism of around 1600 'overlapped at the edges' due to these shared late-medieval origins. ${ }^{39}$ Van Dijkhuizen has also noted that poets of different religious denominations were inspired by the 'affective models of spiritual experience' offered by the late medieval tradition of lyric Passion poetry. ${ }^{40}$

In the case of de Swaen's poem on the passion of Christ and its strong emphasis on affect, Porteman and Smits-Veldt have suggested a possible influence of Franciscan spirituality and Jesuit methods of prayer..$^{41}$ Smit mentions the influence of the Stations of the Cross, a tradition which was being revived in the Southern Low Countries during the Counter-Reformation..$^{42}$ When passing along the different stations, the believer was meant to pause, especially in the run-up to Easter, at key moments from the Passion and meditate on them. In 1623, for example, the Ghent priest Michel Zachmoorter restored an important Stations of the Cross in Ekkergem near Ghent, constructing eighteen stations that had

34 See for instance Van Lieburg and Lindmark, Pietism, revivalism and modernity, which links Pietism to Puritanism and Methodism as well as to Jansenism.

35 Buitendijk, Het calvinisme in de spiegel.

36 Hoppenbrouwers, Oefening in volmaaktheid, 50-52.

37 Roodenburg, 'Empathy in the Making', 6o.

38 Roodenburg, 'Empathy in the Making', 44. See also Roodenburg, 'Continuities or Discontinuities?'. One could draw a line here, as already suggested by scholars like Van Engen, between fifteenth-century Catholic theology and the Reformation, even though we are dealing with an example of the Further Reformation, a movement that was focused on eradicate customs and religious opinions that reminded of the Catholic tradition. See Van Engen, 'Multiple Options'.

39 Karant-Nunn, The Reformation of Feeling, 255.

40 Van Dijkhuizen, Pain and Compassion, 93.

41 Porteman and Smits-Veldt, Een nieuw vaderland voor de muzen, 817.

42 Smits, Kalliope in de Nederlanden, 623. 
been destroyed during the Dutch Revolt. Here, too, the literary and religious experience went hand in hand: the official reopening of this Stations of the Cross was accompanied by a booklet written by Zachmoorter himself (who had literary ambitions), containing meditative texts and prayers, which, like the later text by de Swaen, was to arouse emotional compassion through the verbal and visual representations of Christ's suffering. ${ }^{43}$

Not much is known about de Swaen's specific religious background, other than the fact that he was a Catholic. Based on his knowledge of Latin and Greek, some scholars have assumed that he was educated by the Jesuits - there was a Jesuit college in Dunkirk from the sixteenth century onwards - but this is not certain. ${ }^{44}$ Reference is also often made to his contacts with Capuchins present in Dunkirk, and his occasional poems indicate that de Swaen maintained good contacts with regular and secular clergy in his hometown..$^{45}$ Unfortunately, most studies that attempt to investigate these influences in more detail are highly speculative in nature. ${ }^{46}$ The most concrete starting point for learning more about his spiritual orientation is his active involvement in a Dutch-speaking religious confraternity in Dunkirk, the Broederschap van 't Alderheyligste Sacrement des Autaers tot de Berechtinge der Siecken (Brotherhood of the Most Sacred Sacrament of the Altar for Healing the Sick), which was founded in 1697. A poem written by de Swaen in the year this confraternity was founded stresses the wish of citizens to be involved in the work of the clergy. One of the aims of the confraternity was to support them in their visits to the sick. The poem refers to financial and practical support (such as the ringing of the bell when the priests go out, and the cessation of a rain cover during processions), but also to literary support through the reading of Psalms and religious poetry:

The citizens begin to prepare,

They could not part from the church all day long.

These admonish the neighbours, those provide the light,

They proclaim God's praise with psalms and poetry. ${ }^{47}$

Brotherhoods like this were established in the context of the Counter-Reformation and the promotion of civic piety that should become manifest through a closer involvement of the believer in religious practices and ceremonies. According to his own poem, the brotherhood of de Swaen was involved in the distribution of Holy Communion to the sick who were in danger of dying. In the Flemish town of Roeselare, members of a comparable brotherhood likewise had to attend important processions, mainly by accompanying the clergy. The brotherhood also had to promote the inner devotion of its members. The Roeselare brotherhood had created a devotional booklet for its members that was to serve as the 'spiritual food and source of meditation for an individual life of faith', for instance

43 Porteman, 'Zachmoorter, Michel'.

44 Sabbe, Het leven en de werken, 5.

45 Noote, Pour lire de Swaen, 67-71.

46 See for instance Hardeman, 'Michiel de Swaen'.

47 Cited in Sabbe, Het leven en de werken, 15: 'Hiertoe beginnen sigh de Borgers te bereyden/Die konnen van de kerk geheel den dagh niet scheyden;/Dees maenen de ghebuert, die sorgen voor het licht,/Dees melden Godes lof met Psalmen en Gedicht.' 
to prepare for the Eucharist. ${ }^{8}$ This Catholic culture of devotion was aimed at imagining the deep suffering of Christ in order to understand the mystery of the Eucharist - 'remembering his bitter Suffering and his Death, but also proclaiming and presenting' - before taking communion. ${ }^{49}$ This emphasis on the sacraments should also be seen in the context of the Counter-Reformation, defending religious ceremonies that were banished by the Protestants. ${ }^{50}$

As Joseph de Bousy (d. 27 October 1699) was also a member of de Swaen's brotherhood, the latter's elegy gives an impression of the role that its members played in liturgy, here at a funeral. ${ }^{51}$ It starts with an emotive by way of an address that urges fellow brothers to mourn: 'Mourn, fellow brothers of the Holy Sacrament.' 52 Seeing the great sorrow in the city about the death of de Boussy, however, the lyrical I silences himself and the brotherhood to pave the way for the great sorrow expressed by the entire city:

\footnotetext{
Be silent: I see the whole city captured by pressure and woe,

The sad community with tears on the cheeks

Gathering before the house, while the mournful sound

Of the bells opens up everyone's mouth for complaint and mourning. ${ }^{53}$
}

This imposed silence also works as an emotive because it interrupts the expressions of inner pain that the lyrical I had expressed on behalf of the brotherhood, ending with the following exclamations: 'O woeful loss! O dreary day!'54 These exclamations address the movement from the sorrow within the limited circle of members of the brotherhood, to the awareness that their lamentations should temporarily be silenced in order to make room for a sense of loss that is shared with the entire urban community.

During the Counter-Reformation, religious brotherhoods were seen as important spiritual armies in defending the Catholic faith against heresy, a visible and activist form of piety that also characterised the sodalities of the time, like those founded by the Jesuits. ${ }^{55}$ In Leuven, for instance, extending anti-Jansenist networks of believers was one of the aims of religious brotherhoods around $1700 . .^{6}$ The community-building effect of the brotherhood as it emerges in de Swaen's poem through the shared grieving process could easily be seen in the context of polarisation and social bonding in the context of the Counter-Reformation. ${ }^{57}$ Its social function of bringing devout citizens together went hand in hand with the

48 Therry, 'De broederschap van het Alderheylightse Sacrament', 80.

49 Therry, 'De broederschap van het Alderheylightse Sacrament', 84: 'sijn bitter Lijden ende sijne Doodt indachtig zijn, jae oock vercondigen ende voorstellen'.

50 Dewilde, Corporaties en confrerieën, 91.

51 See also Sabbe, Het leven en de werken, 16; Van der Haven, 'Verdoofde klachten over een stomme mond', 149.

52 De Swaen, Zedelyke rym-wercken, 137: 'Treurt Mede-Broeders van het Heyligh Sacrament'.

53 De Swaen, Zedelyke rym-wercken, 138: 'Stil: 'k sie geheel de Stadt met druck en wee bevangen,/De treurighe Ghemeent' met traenen op de wangen/Vergaedert voor het huys, terwyl het droef gheluyt/Der klocken, ieders mont tot klacht en rouw ontsluyt.'

54 De Swaen, Zedelyke rym-wercken, 137: 'O jammerlijck verlies! ô troosteloozen dagh!'

55 Hoppenbrouwers, Oefening in volmaaktheid, 86; Pollmann, Catholic Identity, 137.

56 Dewilde, Corporaties en confrérieën, 311-312.

57 On community-building in de Swaen's elegies, see also Van der Haven, 'Verdoofde klachten over een stomme mond', $146-150$. 
collective nature of devotional ceremonies the brotherhood had to carry out, together with the clergy. The members of the brotherhood acted in favour of the larger community of believers, which in the poem becomes clear from its silence in favour of the inner pain expressed within the group of bystanders. The anti-heretical militancy of these societies is reflected in words that the anonymous man or woman in the poem expresses, pointing at the collective feelings expressed here as a weapon against heresy:

The zeal of your Soul was just discovered

To the shame of Heresy, to the glory of Christ's Church.

We hoped that through such a Holy Work you would make

The citizen of Zeeland and the obstinate Briton to believe the truth..$^{8}$

\section{A House of Sighs and Tears}

The increased interest in emotions in Protestant poetry of the Dutch Republic around 1650 is mostly attributed to the Further Reformation and the influence of theologians like Voetius. ${ }^{59}$ De Decker has often been associated with this branch of Protestant Pietism. ${ }^{60}$ On the one hand he remained faithful to Reformed orthodoxy, while on the other hand he strongly supported religious tolerance, as is shown by his contacts with and the appreciation he expressed for representatives of other Protestant denominations such as Jacob Arminius, the more liberal theologian and the antipode of Dutch Calvinist orthodoxy, especially in the 1620 s. $^{61}$ What connects De Decker to the more orthodox Pietists such as Voetius, however, is the emphasis in his poetry on the individual and inner experience of faith and the dedication to the work and life of Christ through a process of inner contemplation. He belonged to the intellectual circle around Rembrandt, of which the Pietism is interpreted in an older publication as a reaction to the intellectualism of Calvinist orthodoxy. ${ }^{62}$ These believers were looking for a more personal 'lived faith' that would counterbalance the overly distant and dogmatic view of Christian belief that, in their eyes, characterised Dutch Reformed orthodoxy. ${ }^{63}$

In his Rym-oeffeningen (1659), de Decker published his 'Sighs and tears over my father's corpse, deceased on 16 May 1658', a collection of poems related to the death of his father one year before. The title is taken from the first poem of the collection; the other four poems also have their own title, each of them referring to the addressee of the poem: de Decker's earlier deceased brother in the East Indies, his father's fever, the deceased father himself, and his mother. The lyrical subject presents himself as the poet in the role of the

58 De Swaen, Zedelyke rym-wercken, 138: 'Den yver van uw Ziel begon sigh eerst t'ontdecken/Tot schand der Kettery, tot roem van Christus Kerck/Wy hoopten dat ghy soudt door soo een Heyligh Werck/Den Zeeuw en harden Brit de waerheyt doen ghelooven.'

59 Porteman and Smits-Veldt, Een nieuw vaderland voor de muzen, 658-666.

60 Buitendijk, Het calvinisme in de spiegel, 46.

61 Karsmeijer, De dichter Jeremias de Decker, 81.

62 Visser 't Hooft, Rembrandts weg tot het evangelie, 76.

63 Visser 't Hooft, Rembrandts weg tot het evangelie, 73. 
surviving relative, with the exception of the poem to the mother, in which the lyrical I gives the floor to the father, who admonishes the lamenting mother from his place in heaven.

As Jonathan Culler has recently shown, these forms of address are typical for the lyrical genre, which certainly also applies to the early modern period and Dutch-language poetry. ${ }^{64}$ Lyric poetry only rarely speaks directly to the reader. Mostly it speaks to an addressee that could never be addressed in reality, be it an abstraction such as 'love' or a deceased person, as in the elegy. Roland Greene refers to the 'strangeness' of the lyrical language in elegy, which brings something or someone to life, making it present through language, while the poem itself is about the absence of someone or something. ${ }^{65}$ In the epicedium this leads to an interesting contradiction that is brought to a head by de Decker when, in the other poems of the collection, he adds to the already impossible address of his dead father, the address of his dead brother, of his father's illness (his poem 'To the fever'), and finally his mother, addressed by his dead father.

If we look more closely at the collection as a whole, it turns out that each of the poems highlights at least one of the rhetorical functions of the early modern funeral elegy as discussed above: luctus, laus, and consolatio. All three are present, although most attention is paid to the inner pain of loss - a fact that is also apparent from the title, which refers to the 'sighs and tears' of the lyrical subject. Those sighs and tears receive the most attention in the first poem, asking the 'southern wind' to join the sad sighing of the lyrical I, during a spring that should no longer carry the name of that season because 'all the air is dressed in mourning' and 'spring is not what is used to be'. ${ }^{66}$ The luctus is continued in the address of the deceased brother, who is 'blessed' because of his early death, which has saved him from witnessing the extreme suffering of his family: 'O blessed is he who does not see our grief/Our bitter family-mourning/And does not hear our gestures around the corpse. ${ }^{67}$ The luctus in this poem goes together with the laus, listing the qualities of the father that are remembered through the address of the deceased brother as a fellow witness. The poem 'To the fever' has the character of an accusation, but is certainly also an example of luctus, because it contains an accurate description of the father's sickbed and his perseverance. In the poem 'To my Father', the laus dominates again, accompanied by the melancholy of the lyrical I caused by his loss, while in the address of the mother by the dead father the consolatio clearly takes centre stage.

None of the individual poems contains all three of the rhetorical functions of the funeral elegy. One could even say that by separating each function, de Decker deconstructs the rhetorical structure of the early modern elegy: each of the functions gains meaning separately, without, for example, the inner pain necessarily being overshadowed by comfort. In fact, this lyrical cycle brings to the fore the inner pain of loss, with consolation only becoming an obligatory element at the end of the very last poem. In the first two poems, much attention is paid to what comes before the inner pain of loss: the realisation that the father

64 Culler, Theory of the Lyric. For Dutch poetry, see Van der Haven and Pieters (eds.), Lyric Address in Dutch Poetry.

65 Greene, 'Elegy, Hymn, Epithalamium, Ode', 315.

66 De Decker, Rym-oeffeningen, 94: 'all de lucht gekleed in rou', 'Lent geen' lente en sy gelijck'.

67 De Decker, Rym-oeffeningen, 95: 'O saligh ghy, die ons verdriet,/Ons' bittren Huys-rou niet en siet,/En niet en hoort ons' lijckgebaren.' 
has died through the sensual observation of how death occurs in the body of his father. First, the lyrical I has to realise that death really has arrived at his family home, taking away his father, before the inner pain and grief of death can be felt at all.

The careful consideration in these poems of a living body transformed into a corpse has a rhetorical function, namely that of the evidentia: the accurate description of an event that, according to Quintilian, should move the mind of the reader in such a way that he or she feels like a witness - in this case the occurrence of death. ${ }^{68}$ The persuasive technique of suggesting a 'living presence' through words, images, and theatrical techniques was an important element of baroque aesthetics, also in regard to the element of death and violence. ${ }^{69}$ In de Decker's visualisation of death through words, each of the observations emphasises the transformation of a healthy body into a sick body that will die soon. Each word is carefully chosen to 'paint' the bodily effects of this transformation: the languishing of the mouth, the moulding and peeling of the lips, the slackening of the tongue, the dry and dead appearance of the face, and the stiffening of the hands. In seven stances, the lyrical I describes this process of mortification step by step, ending in the following verse:

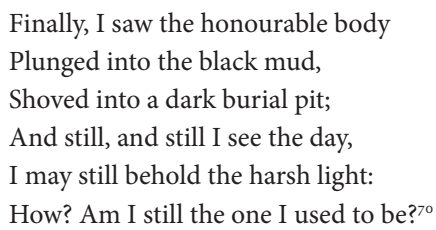

The luctus can only take place after this process of sensual perception has reached its peak in the mind of the lyrical I, realising that the father is dead and that his living body has become a corpse buried in the black mud and 'shoved' in a pit, using a Dutch verb here (douwen) that already had a disrespectful connotation in the seventeenth century. In the perception of death, there seems to be some resistance in these lines between seeing all these terrible things happening, the wish not to see them, and the question if the lyrical I deserves to see the death of his father. The last lines even seem to contain a death wish, which is confirmed in the stanza that follows, in which the sorrow becomes so strong that it turns into embarrassment about the fact that the son still lives, whereas the father has died, which is described as a brutality and 'an impossibility of being'.

In this poem, mourning is unbearable for the lyrical I, a situation reflected in the following poem that involves a fellow witness in the process of mourning: the dead brother who no longer has to see what has happened to his father, which actually means that he is better off than the lyrical I himself. Mourning appears to be impossible, because the lyrical I does not consider his own soul worthy, being 'too lumpish and too harsh/To carry out such noble mourning'.${ }^{11}$ For comparison, he recalls the more refined mourning of Louis, Duke

68 Konst, 'Theorie en praktijk van de hartstochten', 204, n. 20.

69 Bussels and Van Oostveldt, 'The Massacre of the Innocents', 67.

70 De Decker, Rym-oeffeningen, 99: 'Ten laasten heb ick't waerde lijck/Sien domp'len onder't swerte slijck./Sien in den duystren graf-kuyl douwen;/En noch, en noch sie ick den dag;/Noch derf ick harde 't licht aenschouwen:/ Hoe? Ben ick oock noch die ick plag?'

71 De Decker, Rym-oeffeningen, 100: 'te boersch en hard/Om aen soo edlen rou te splyten'. 
of Montpensier, who, in 1496, visited the grave of his father in Pozzuoli, Italy. The pain of loss that the young duke has carried in his heart since the death of his father was too big to bear. He asked for an opening of the grave, but when he saw the remains of his father, the duke felt such a deep inner pain that the young man died before the grave of his father. ${ }^{72}$ The uncertainty expressed by the lyrical I in de Decker's poem regarding the quality of his own mourning when compared to this dramatic French-Italian example, should be seen as a response to the dominant opinion about mourning in Calvinism. The Dutch Reformed Church objected to mourning practices quite explicitly and more pointedly compared with, for instance, Lutheran churches. ${ }^{73}$ This moment of insecurity is a good example of emotional suffering induced by a goal conflict, here between the religious conventions and the individual wish of the lyrical I to mourn and to express his pain of loss.

The presentation of mourning in this example is contrary to the lesson from Ecclesiastes which states that it is good to mourn (Eccl. 7:3). The house of mourning in the case of de Decker is a depressing and soundless place, a 'quiet room', 'rough and laden with many disasters' ${ }^{74}$ The brother who has already passed away is blessed because he is saved from seeing the mourning of his family members. ${ }^{75}$ Apart from decoupling the luctus from the consolatio, then, the poem seems to pose questions here about the public character of mourning. Mourning is the inner grief shown to others, but here there is a grief that wants to remain unseen, which means that it should not be turned into mourning. There is the option (and there also are references to) mourning, but the bitterness of the heart and the embarrassment about one's own survival are too heavy to share in the family's pain of loss.

\section{Beholding a Corpse}

An important moment in the grieving process as delineated in de Decker's poems about his father is the moment of perception of death that takes place through a contemplation of the living body's transformation into a corpse. This is also shown in de Swaen's epicedium on de Boussy, where mourning can only follow upon the shared awareness of his death among the members of the brotherhood. The poem urges them to look at his dead body and this sensual experience is described in relation with memories about his body when it was still alive:

See his body there, succumbed,

Lying stiff and cold. His tireless hand,

Which every day illuminated the church, with the burning

Of a hundred Torches, to the glory and praise of the Lord,

Is motionless. His tongue, which was used so wisely

And gracefully in the multiplication of true faith,

Now lies like a stone that knows of no movement.

72 Guicciardini, Storia d'Italia, 512.

73 Karant-Nunn, The Reformation of Feeling, 214.

74 De Decker, Rym-oeffeningen, 100: 'stil vertreck', 'grof en swanger van veel rampen'.

75 De Decker, Rym-oeffeningen, 100. 
His Heart, his fiery Heart, imbued with Love,

Which steadily emits to his God a thousand sighs, a thousand sparks

Of pure love, is without a pulse. ${ }^{76}$

The body of the deceased is explored step by step, from the stiffened hand, the ossified tongue, to the heart that stopped beating - each of these body parts receive separate attention. The function of this detailed investigation is twofold: to make people aware of the priest's death and to praise and remember him. In doing so, the corpse becomes the physical starting point of a meditation on the death of a dear one who remains imaginatively within the embrace of the living' ${ }^{77}$

The importance of seeing the corpse of the deceased and the contemplation that should follow is also reflected in another poem by de Swaen. Dated 27 August 1702, it concerns the death of the Dunkirk notary Thomas van Caester. ${ }^{78}$ It is an exceptional epicedium because it is not about a natural death, but about a murder. According to the poem, he was stabbed to death in his office by an unknown person. Van Caester and de Swaen were both members of the main Dunkirk chamber of rhetoric; they probably knew each other well and there may even have been a friendship. This may be the reason why the pain of loss is given more emphasis and a more personal interpretation when compared to the more formal elegies about the two Dunkirk clergymen. ${ }^{79}$

The third stanza describes the 'autopsy' by the lyrical I. Like in de Decker's poem, the description of the corpse is rather factual, focusing on the colour of the face, the silent mouth, and the wound made by the murderer's knife from which the blood still flows. The representation is literally sensational. The phrase 'I saw' is repeated several times, to indicate that the description of the deceased is gruesome and far from complete. In the description, the eye catches on the most shocking details, like the mention of 'bubbling blood' emanating from the place where the knife has ripped open the body. The lyrical subject makes our eyes wander over the dead body, preparing the reader to experience an emotional response of empathy. The visualisation of the body certainly can be called theatrical, not only because of the emphasis on the horrifying visual details, but also regarding the aim of being moved inwardly (movere) in order to experience compassion with the gruesome fate of the victim (commiseratio). Both rhetorical principles were important components of Aristotelian poetics, with which de Swaen was certainly familiar with. ${ }^{80}$ The lyrical I suffers with the deceased and

76 De Swaen, Zedelyke rym-wercken, 137-138: 'Siet sijn Lichaem daer, besweken/Neer-liggen stijf en koudt. Sijn onvermoeyde handt/Die daghelijcx de kerk verlichte, met den brandt/Van hondert Fackelen, tot roemen lof des Heeren,/Is onbeweghelijck. Sijn tongh die in 't vermeeren/Van 't waer Gheloof, soo wijs en deftigh wierdt besteedt,/Light nu ghelijck een steen, die van geen roeringh weet./Sijn Hert, sijn vyerigh Hert, door Liefde g'heel doordroncken,/Dat stadigh naer sijn Godt, duyst suchten, duysent voncken/Van reyne min uyt-schoot, is sonder ader-slagh.'

77 Laqueur, The Work of the Dead, 59.

78 The discussion of this elegy is based on Van der Haven, 'Verdoofde klachten over een stomme mond', 142-146, which offers a more detailed analysis.

79 See also Geerdink's similar conclusions regarding the elegies by Jan Vos and Katharijna Lescailje: Geerdink, "'Het hart der dichters".

80 Konst, 'Theorie en praktijk van de hartstochten'; Meeus, '1687. Michiel de Swaen'. 
invites the reader implicitly to copy this emphatic response, expressing the following emotives:

Oh! What woe moved me at that moment!

The sight of your blood penetrated my heart,

And the sword of pity came close

To make me lose my strength on your dead body. ${ }^{81}$

Unlike the epicedium on de Bousy, there is no consolatio in the poem about van Caester. Although Mary is called upon in the hope that she will take care of the soul of the deceased, the consoling effect of this trust in the soul's salvation is not mentioned. Rather, we could say that this comfort is explicitly rejected, or at least postponed until the end of the poem. The lyrical I broadens itself to a 'lyrical we' in the poem's last stanza, where, referring to the members of the chamber of rhetoric, the poem turns into a collective experience of sadness that does not allow for any comfort (according to the poem's subtitle: 'For a testimony of their Sorrow, for his loss'). Apollo himself is addressed in these lines with the request to keep his muses in check, not allowing them to sing in a more encouraging way. Now is not the time for comforting chants, but for lament and sounds of grief and death. The last lines of the last stanza are very clear regarding this wish: 'Arrange the playing of flute and strings according to our and your condition./Oh! oh! We can touch neither lyre nor cither here,/ Only to produce a sad and dead sound. ${ }^{82}$

\section{Conclusion}

In the modest corpus of funerary elegies written by de Decker and de Swaen, there is a strong relationship between the individual pain of loss and how these feelings are shared with others. The feelings are made tangible through the perspective of a lyrical I, thus providing a more intimate perspective on the pain of loss. Grief can be felt more deeply in those moments of beholding (before the mind's eye) the dead body of the deceased. In most of the poems, this intimacy is then shared with a broader community of mourners, who are addressed in the poem with emotives to stop mourning and to join the lyrical I in taking the next step towards consolation and joy.

An important distinction, however, has to be made between the two elegies that deal with cases of personal loss of the two poets, and the more formal poems that closely follow the rhetorical structure of classical elegy. In these former elegies, comfort makes room for either a continuation of mourning (de Swaen), or a deepening of grief before comfort can be received (de Decker). In contrast, the formal elegies written for clergymen lay emphasis on consolatio through God's message of salvation.

81 De Swaen, Werken van Michiel de Swaen, vi, 149-150: 'Ach! met wat weedom was ik dier tyt ingenomen!/'t Aenschouwen van uw bloet drongh midden door myn hert,/En 't schilde weynigh of het sweert van medesmert/ Had op uw doode lyk myn crachten doen begeven.'

82 De Swaen, Werken van Michiel de Swaen, vi, 151: 'Schik fluyt- en snare-spel naer ons' en uwen staet./Och! och! wy connen nu nogh lier, nogh cyther raken,/Dan om een treurgeklank en doots geluyt te maken.' 
Both within the emotional regimes of the Counter-Reformation and the Further Reformation, religious comfort ultimately prevailed over other emotions. Within a Catholic context, only temporal grief is allowed and should be overcome by the delight over the souls' salvation, whereas in the context of Calvinism mourning practices in general were considered as problematic, especially when grief failed to culminate in an awareness of a believer's shortcomings and sins. The emotional suffering caused by the two regimes is different: in de Swaen's poem about van Caester, the suffering is created by a goal conflict between mourning and consolation, while in de Decker's poem about his father, there is a goal conflict between grief and mourning. Whereas de Swaen's lyrical I asks for a continuation of mourning, together with others, the lyrical I of de Decker's poem does not even reach that emotional stage, feeling himself unworthy to mourn at all, preferring to foster the inner pain instead of sharing it with others. Hence, this essay has unravelled the differences between the elegies written after the passing away of a public person, and the poems about a death in the private sphere in which poetry functioned more as a means of 'emotional refuge'.

\section{Bibliography}

Brady, Andrea, English Funerary Elegy in the Seventeenth Century. Laws in Mourning (Basingstoke 2006).

Buitendijk, Willem Jan Cornelis, Het calvinisme in de spiegel van de Zuidnederlandse literatuur der Contra-Reformatie (Groningen 1942).

Bussels, Stijn, and Bram Van Oostveldt, 'The Massacre of the Innocents. Infanticide and Solace in the Seventeenth-Century Low Countries', in Tomas Macotay, Cornelis van der Haven, and Karel Vanhaesebrouck (eds.), The Hurt(ful) Body. Performing and Beholding Pain, 160o-180o (Manchester 2017) 49-73.

Culler, Jonathan, Theory of the Lyric (Cambridge 2015).

Decker, Jeremias de, Rym-oeffeningen, Verdeelt in dry Boecken vervattende gedichten van verscheyden stijl en stoffe (Amsterdam: Abraham van Blancken, 1659).

Decker, Jeremias de, Goede Vrydag ofte Het Lijden onses Heeren Jesu Christi. W.J.C. Buitendijk (ed.) (Culemborg 1978).

Dewilde, Brecht, Corporaties en confrerieën in conflict. Leuven 160o-1750. PhD diss., KU Leuven, 2012.

Dijkhuizen, Jan Frans van, Pain and Compassion in Early Modern English Literature and Culture (Cambridge 2012).

Engen, John Van, 'Multiple Options. The World of the Fifteenth-Century Church', Church History 77 (2008/2) 257-284.

Geerdink, Nina, 'Rouw om een "cieraat grooter vrouwen". Lijkdichten bij de dood van Maria Stuart (1695) door mannen en vrouwen', Historica 32 (2003/1) 3-5.

Geerdink, Nina, “'Het hart der dichters”. Persoonlijke thema's in de gelegenheidspoëzie van Jan Vos en Katharina Lescailje', Vooys 22 (2004) 50-64.

Greene, Roland, 'Elegy, Hymn, Epithalamium, Ode. Some Renaissance Reinterpretations', in Patrick Cheney and Philip Hardie (eds.), The Oxford History of Classical Reception in English Literature, 5 vols., (Oxford, 2015), II, 311-344.

Guicciardini, Francesco, Storia d'Italia. Ettore Mazzali (ed.) (Milan 1988).

Hardeman, R., 'Michiel de Swaen (1654-1707). De vlaamsche dichter van het H. Hart', Bode van het H. Hart (1938) 1-24.

Haven, Cornelis van der, and Jürgen Pieters (eds.), Lyric address in Dutch literature, 1250-180o (Amsterdam 2018). 
Haven, Kornee van der, 'Verdoofde klachten over een stomme mond. De vroegmoderne lijkzang als een emotionele praktijk in het werk van Michiel de Swaen', Verslagen en Mededelingen van de KANTL 129 (2019/2) 131-154.

Hodgson, Elizabeth, 'Mourning Eve, Mourning Milton in Paradise Lost', Early Modern Literary Studies 11 (2005/1) 1-32.

Hoppenbrouwers, Frans, Oefening in volmaaktheid. De zeventiende-eeuwse rooms-katholieke spiritualiteit in de Republiek (The Hague 1996).

Hotton, Godefroy, La pieté éprouvée. Représentée en homélies familières et populaires, sur les trois prémiers chapitres de l'histoire de Job (Amsterdam: Boudewijn De Preys, 1648).

Karant-Nunn, Susan C., The Reformation of Feeling. Shaping the Religious Emotions in Early Modern Germany (Oxford 2010).

Karsemeijer, Jan, De dichter Jeremias de Decker (Amsterdam 1934).

Konst, Jan, 'De retorica van het "movere" in Jeremias de Deckers Goede Vrydag ofte het Lijden onses Heeren Jesu Christi', De nieuwe taalgids 83 (1990) 298-312.

Konst, Jan, 'Theorie en praktijk van de hartstochten. Het martelaarsdrama Catharina van Michiel de Swaen', Spiegel der Letteren 38 (1996/2-3) 113-134.

Laqueur, Thomas W., The Work of the Dead. A Cultural History of Mortal Remains (Princeton 2015).

Lieburg, Fred van, and Daniel Lindmark, Pietism, Revivalism and Modernity, 1650-1850 (Newcastle 2008).

Meeus, Hubert, ' 1687 . Michiel de Swaen wordt Prince van de rederijkerskamer De Kersauwe in Duinkerke. De rederijkstraditie in Noord-Frankrijk', in Rob Erenstein (ed.), Een theatergeschiedenis der Nederlanden. Tien eeuwen drama en theater in Nederland en Vlaanderen (Amsterdam 1996) 278-283.

Noote, Robert, Cyriel Moeyaert, and Marcel Janssen, Pour lire de Swaen. La vie et l'ouvre de Michel de Swaen (1654-1707) (s.l. 1994).

Pollmann, Judith, Catholic Identity and the Revolt of the Netherlands, 1520-1635 (Oxford 2011).

Porteman, Karel, '1701-1702. Michiel de Swaen schrijft een klacht na een bezoek aan Holland', in Riet Schenkeveld-van der Dussen (ed.), Nederlandse Literatuur, een geschiedenis (Groningen 1993) 303-308.

Porteman, Karel, 'Zachmoorter, Michel', Literair Gent, http://literairgent.be/lexicon/auteurs/zachmoorter-michel/ (Accessed on 4 May 2020).

Porteman, Karel, and Mieke Smits-Veldt, Een nieuw vaderland voor de muzen. Geschiedenis van de Nederlandse literatuur 1560-1700 (Amsterdam 2008).

Reddy, William, The Navigation of Feeling. A Framework for the History of Emotions (Cambridge 2001).

Roodenburg, Herman, 'Empathy in the Making. Crafting the Believer's Emotions in the Late Medieval Low Countries', BMGN/Low Countries Historical Review 129 (2014/2) 42-62.

Roodenburg, Herman, 'Continuities or Discontinuities? Exploring Affective Piety in the SixteenthCentury Low Countries', in Ethan Kavaler and Anne-Laure Van Bruaene (eds.), Netherlandish Culture in the Sixteenth Century. Urban Perspectives (Turnhout 2017) 311-328.

Sabbe, Maurits, Het leven en de werken van Michiel de Swaen (Brussels 1905).

Smit, Wisse Alfred Pierre, Kalliope in de Nederlanden. Het Renaissancistisch-klassicistische epos van 1550 tot 1850 (Assen 1983).

Swaen, Michiel de, Zedelyke rym-wercken en christelycke gedachten (Dunkirk: Pieter Labus, 1722).

Swaen, Michiel de, Werken van Michiel de Swaen, 6 vols. Frans Jozef Vital Celen, Camille Huysmans, and Maurits Sabbe (eds.) (Antwerpen 1928-1934).

Therry, Marc, 'De broederschap van het Alderheylighste Sacrament des Autaers te Roeselare (1728-1792). Barokke vroomheid en dechristianisatie?', Rollariensia. Jaarboek van het geschied-en oudheidkundig genootschap van Roeselare en ommeland 13 (1981) 64-107.

Visser't Hooft, Willem Adolph, Rembrandts weg tot het evangelie (Amsterdam 1956).

Voetius, Gisbertus, De praktijk der godzaligheid. Cornelis Adrianus de Niet (ed.) (Utrecht 1996).

Witstein, Sonja F., Funeraire poëzie in de Nederlandse renaissance. Enkele funeraire gedichten van Heinsius, Hooft, Huygens en Vondel bezien tegen de achtergrond van de theorie betreffende het genre (Assen 1969). 